\title{
PICTURE-WISE JUST NOTICEABLE DIFFERENCE PREDICTION MODEL FOR JPEG IMAGE QUALITY ASSESSMENT
}

\author{
Boban P. Bondžulića, Boban Z. Pavlovićb, \\ Nenad M. Stojanovićc, Vladimir S. Petrovićd \\ a University of Defence in Belgrade, Military Academy, Department of \\ Telecommunications and Informatics, Belgrade, Republic of Serbia, \\ e-mail: bondzulici@yahoo.com, \\ ORCID iD: -https://orcid.org/0000-0002-8850-9842 \\ b University of Defence in Belgrade, Military Academy, Department of \\ Telecommunications and Informatics, Belgrade, Republic of Serbia, \\ e-mail: bobanpav@yahoo.com, corresponding author, \\ ORCID iD: https://orcid.org/0000-0002-5476-7894 \\ c University of Defence in Belgrade, Military Academy, Department of \\ Telecommunications and Informatics, Belgrade, Republic of Serbia, \\ e-mail:nivzvk@hotmail.com, \\ ORCID iD: Chttps://orcid.org/0000-0001-9328-5348 \\ d University of Novi Sad, Faculty of Technical Sciences, \\ Novi Sad, Republic of Serbia, \\ e-mail: vpetrovic@visaris.com \\ ORCID iD: Dhttps://orcid.org/0000-0002-8299-8999
}

DOI: 10.5937/vojtehg70-34739; https://doi.org/10.5937/vojtehg70-34739

FIELD: Telecommunications ARTICLE TYPE: Original scientific paper

\begin{abstract}
Summary:
Introduction/purpose: The paper presents interesting research related to the performance analysis of the picture-wise just noticeable difference (JND) prediction model and its application in the quality assessment of images with JPEG compression.

Methods: The performance analysis of the JND model was conducted in an indirect way by using the publicly available results of subject-rated image datasets with the separation of images into two classes (above and below the threshold of visible differences). In the performance analysis of the JND prediction model and image quality assessment, five image datasets were used, four of which come from the visible wavelength range, and one dataset is intended for remote sensing and surveillance with images from the infrared part of the electromagnetic spectrum.
\end{abstract}

ACKNOWLEDGMENT:

This research has been a part of Project No. VA-TT/3/20-22 supported by the Ministry of Defence, Republic of Serbia. 
Results: The paper shows that using a picture-wise JND model, subjective image quality assessment scores can be estimated with better accuracy, leading to significant performance improvements of the traditional peak signal-to-noise ratio (PSNR). The gain achieved by introducing the picture-wise JND model in the objective assessment depends on the chosen dataset and the results of the initial simple to compute PSNR measure, and it was obtained on all five datasets. The mean linear correlation coefficient (for five datasets) between subjective and PSNR objective quality estimates increased from $74 \%$ (traditional PSNR) to 90\% (picture-wise JND PSNR).

Conclusion: Further improvement of the JND-based objective measure can be obtained by improving the picture-wise model of JND prediction.

Key words: just noticeable difference, JPEG compression, peak signalto-noise ratio, subjective and objective image quality assessment.

\section{Introduction}

With the rapid development of systems for digital processing, transmission and display of images and videos, there has been a growing interest in efficient image/video compression techniques (Lu et al, 2021). Among the techniques intended for image compression, the JPEG technique (Wallace, 1992), (Pennebaker \& Mitchell, 1993) has been the most widely accepted for more than 25 years. The original JPEG development team members emphasize that the longevity of this technique is a consequence of well-defined mandatory conditions that it had to meet and fundamental components such as fast discrete cosine transform, psychovisual quantization, modeling, encoding, a royalty-free baseline, progressive modes, lossless compression support and realtime implementation (Hudson et al, 2017), (Hudson et al, 2018). The JPEG technique still meets the average user demand, so it is to be expected that it will be present in the coming decades.

Image compression techniques, along with the elimination of coding and spatial redundancy, use some of the characteristics of the human visual system (HVS), i.e. use visual redundancy. One of the characteristics is related to the just noticeable difference (JND) threshold. JND, as a perceptual threshold in image processing, is used in perceptual image compression (Tian et al, 2020), (Wang et al, 2019), and can also be used in objective image quality assessment (Toprak \& Yalman, 2017), (Seo et al, 2021). The first and most significant JND threshold/point refers to the transition between a pristine and an image with visible distortions, or rather the transition from perceptually lossless 


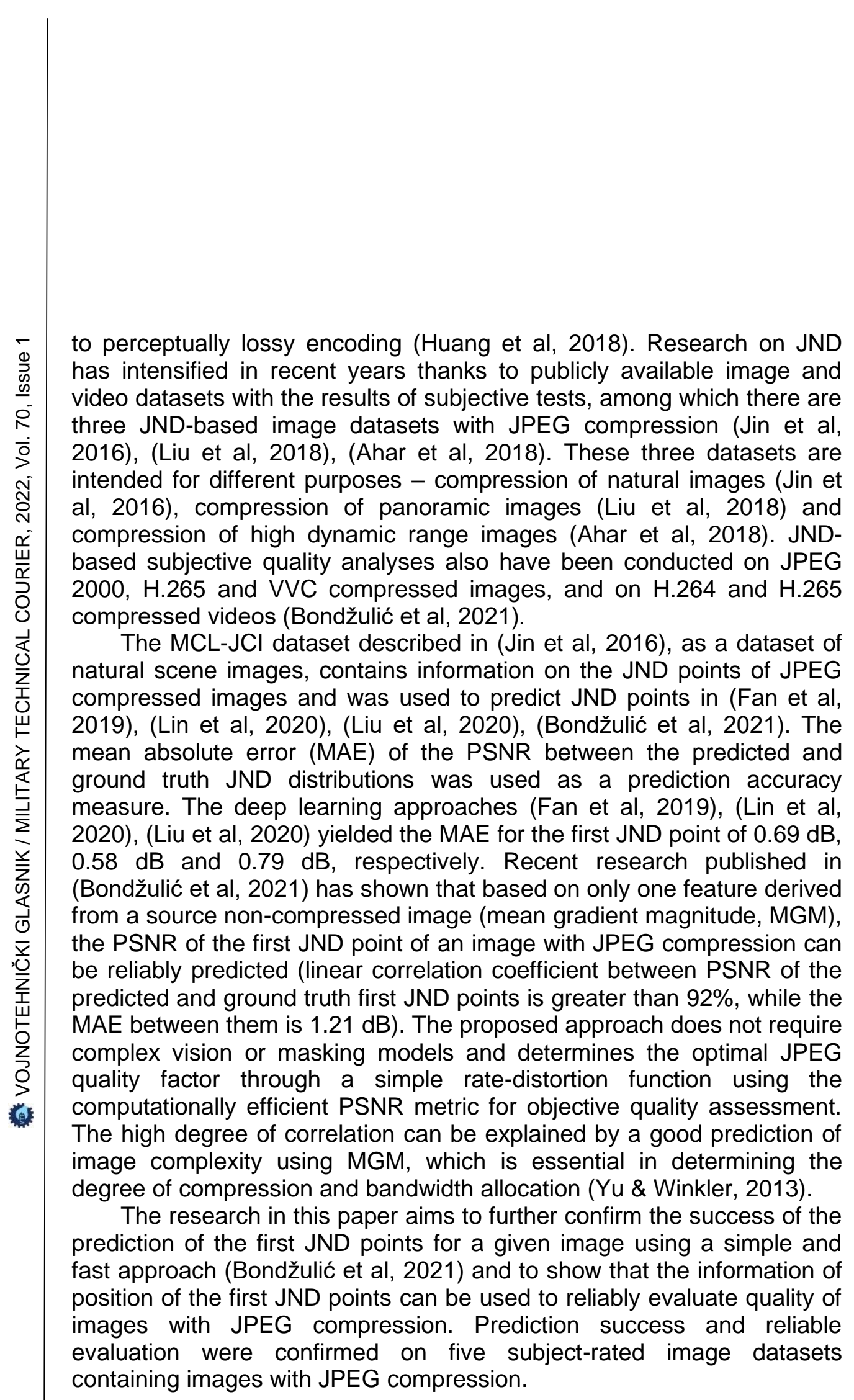




\section{Prediction of the first JND point for JPEG compressed images}

The quality factor (QF), whose values range from 0 to 100 , has been used to control the quality of JPEG compressed images. Higher QF values correspond to better quality images. Although one can choose a QF from 0 to 100, with an increment equal to one, recent research has shown that observers can distinguish a finite number of image quality levels (four to eight), and that the relationship between perceptual distortions and a bit-rate/distortion level is not a continuous but a step function (Jin et al, 2016). The steps of this function represent the JND points. The first among them, and at the same time the most important JND point, refers to the maximum difference between the original and the test image that the HVS will not notice (Li et al, 2020), (Bondžulić et al, 2017). This transition point between the original image and the images with visible degradations also represents the transition from perceptually lossless to perceptually lossy encoding. The second JND point is obtained by detecting noticeable differences from the first JND point (anchor), i.e. lower JND points are used as anchors to determine higher JND points.

Figure 1 shows the original uncompressed image from the MCL-JCI dataset (Jin et al, 2016), its stepwise distribution of JND points and the regions of the original image and images corresponding to JND points. The results of subjective tests were given through the stair quality function (SQF), which represents the normalized cumulative sum of the JND function, and was obtained by analysing and post-processing raw JND data. The height of the SQF function for a boundary point with $\mathrm{QF}=100$ is equal to one and defines the maximum possible quality. The first drop in quality corresponds to the first JND point (JND \#1), and its height corresponds to subjective quality. This point corresponds to the image with $\mathrm{QF}=35$, and its subjective quality is $\mathrm{SQF}=0.92$. The position of the first JND point depends on the image content and for 50 source images from the MCL-JCl dataset these positions were obtained for a wide range of QF values, from 25 to 70 (Jin et al, 2016).

The regions in Figure 1 show visible differences between the images corresponding to the higher JND points (JND \#2 and JND \#3) and the region of the original image.

Prediction of the first JND point for JPEG compressed images can be achieved in the PSNR, QF, and bits per pixel (bpp) domains, but researchers suggested using the PSNR domain to predict the first JND point (Liu et al, 2020), (Bondžulić et al, 2021). 


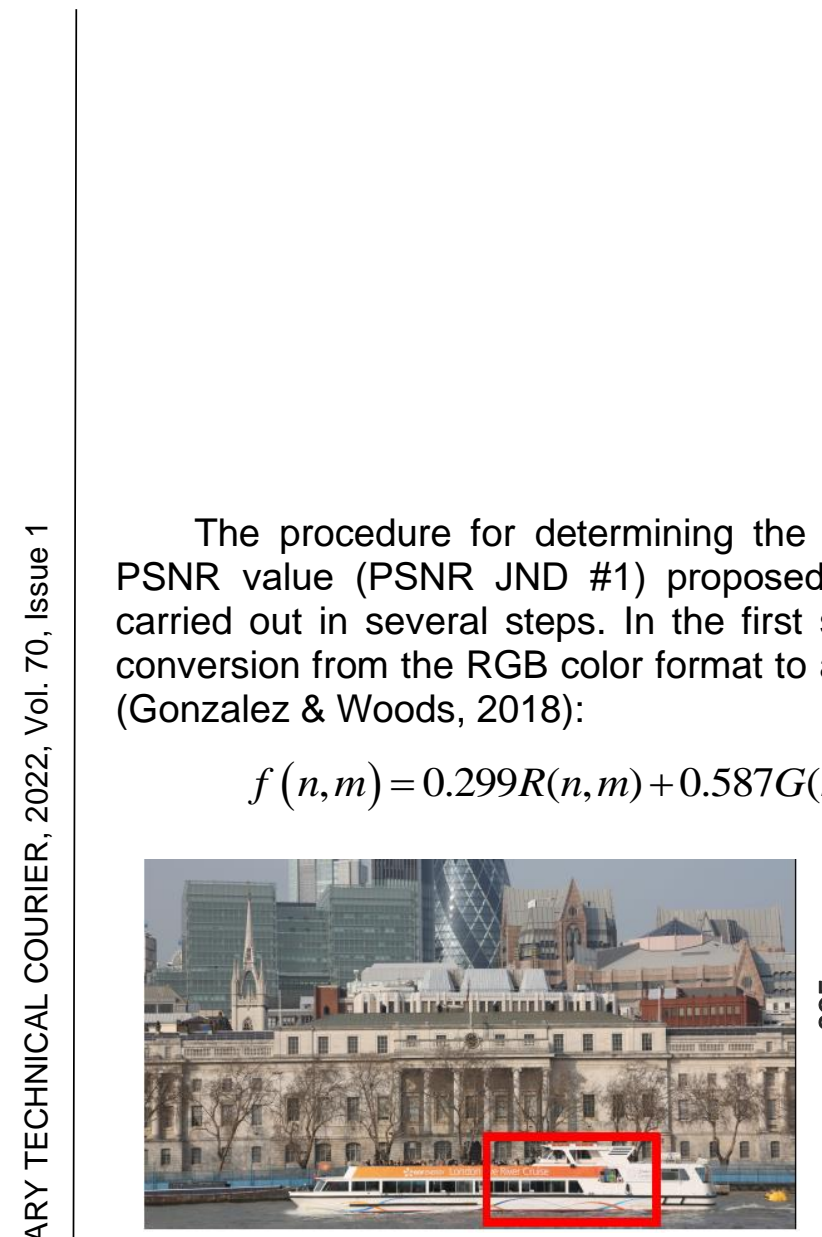

(a)

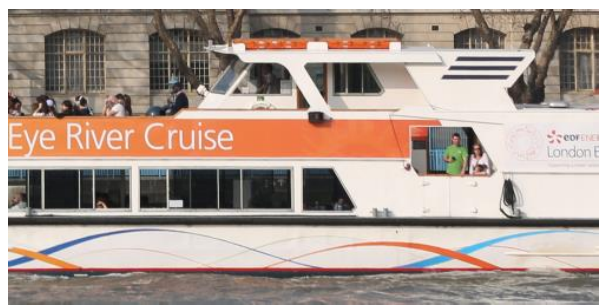

(c) original

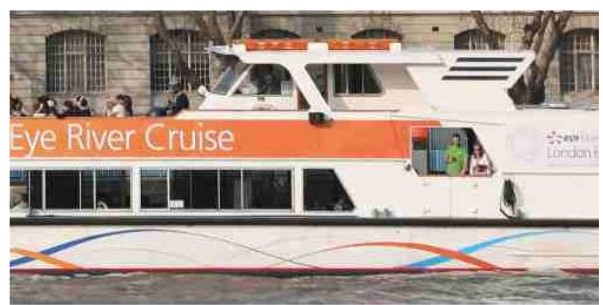

(e) JND \#2 (QF=21, $S Q F=0.65)$

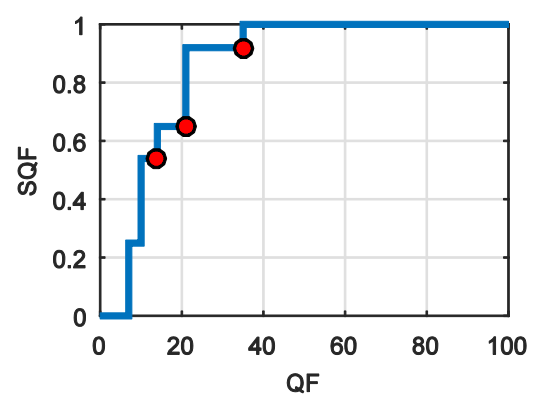

(b)

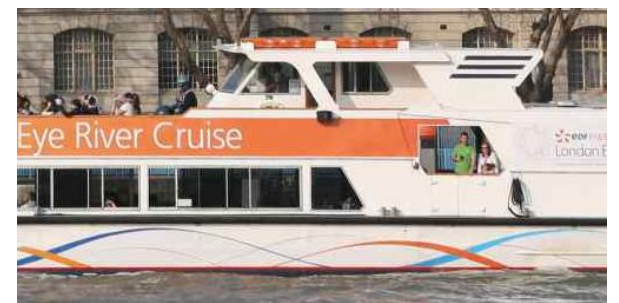

(d) JND \#1 (QF=35, SQF=0.92)

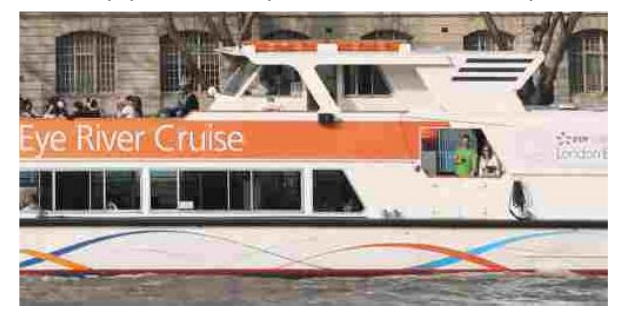

(f) JND \#3 (QF=14, SQF=0.54)

Figure 1 - (a) (b) original image rich in detail and its SQF function, (c) (d) (e) and (f) regions of the original image and compressed images corresponding to the JND points Puc. 1 - (a) (b) исходное изображение, богатое деталями, и его фуннкция SQF, (c)

(d) (e) и (f) области исходного изображения и сжатых изображений, соответствующие точкам JND

Слика 1 - (a), (b) - оригинална слика богата детаљима и њена SQF функција, (c), (d), (e) u (f) - региони оригиналне слике и компримованих слика који одговарају JND тачкама 
In the second step, the responses $g_{x}$ and $g_{y}$ of the grayscale image to the 2D Sobel filters are determined:

$$
\begin{gathered}
g_{x}(n, m)=f(n+1, m-1)+2 f(n+1, m)+f(n+1, m+1) \\
-[f(n-1, m-1)+2 f(n-1, m)+f(n-1, m+1)]
\end{gathered}
$$

and

$$
\begin{gathered}
g_{y}(n, m)=f(n-1, m+1)+2 f(n, m+1)+f(n+1, m+1) \\
-[f(n-1, m-1)+2 f(n, m-1)+f(n+1, m-1)]
\end{gathered} .
$$

From the resulting $g_{x}$ and $g_{y}$ oriented gradient components, the MGM information is easily obtained according to:

$$
M G M=\frac{1}{N M} \sum_{\forall n, m} \frac{1}{g_{\max }} \sqrt{g_{x}^{2}(n, m)+g_{y}^{2}(n, m)},
$$

where $g_{\max }$ is the experimentally determined maximum magnitude value, taken as $g_{\max }=4.472$ for grayscale images with a dynamic range 0 to 1 (image $\mathbf{f}$ which is an 8-bit unsigned integer array with a range of 0 to 255 is linearly scaled to a dynamic range of 0 to 1 with a double-precision 64bit format) (Bondžulić et al, 2021).

The PSNR JND \#1 prediction is determined based on the MGM information as:

$$
\operatorname{PSNR}(M G M)=\left\{\begin{array}{c}
2115.5 M G M^{2}-377 M G M+46.4, M G M \leq 0.0896 \\
29.58, M G M>0.0896
\end{array},\right.
$$

and this mapping function is shown in Figure 2.

The optimal values of the coefficients in Eq. (5) were determined based on the results of subjective tests on the MCL-JCl dataset (Bondžulić et al, 2021).

Figure 2 shows that, with increasing MGM, the value of PSNR prediction decreases, where for $M G M=0.0896$ the mapping function reaches its minimum value $\left(P S N R_{\min }=29.58 \mathrm{~dB}\right)$. This can be explained by the influence of contrast and texture that are important for visibility masking estimation because in the regions that contain more nonuniform contents more distortion can be tolerated than in the regions with homogeneous content. Furthermore, block-based JPEG coding suppresses high-frequency components. In the homogeneous regions with gradual color/intensity change, the blocking artifact is visible to observers. In contrast, the distortion is less obvious in the textured regions (Jin et al, 2016). 


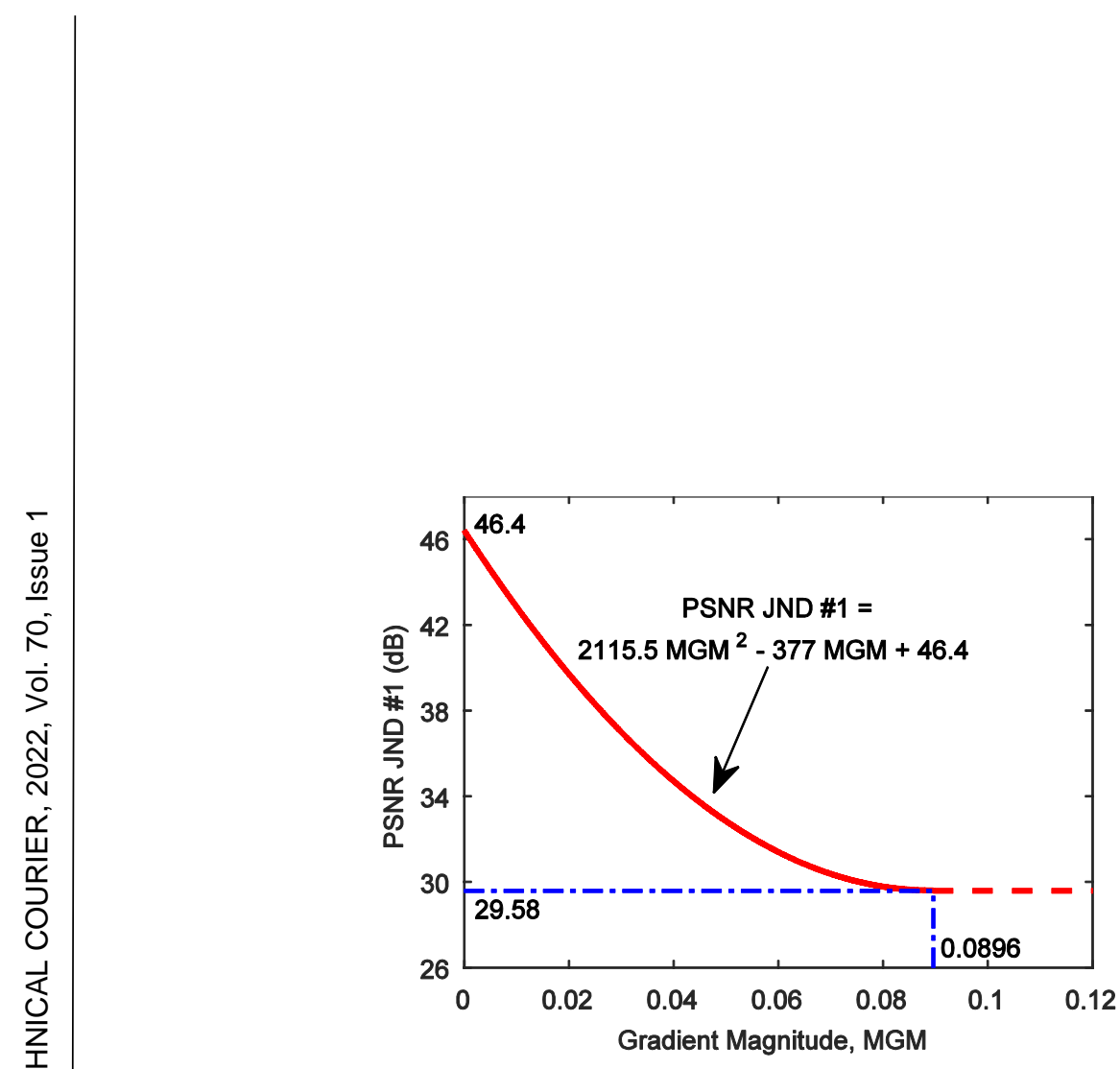

Figure 2 - PSNR prediction of the first JND point based on the mean gradient magnitude Puc. 2 - Прогноз PSNR первой точки JND на основании средней величины градиента

Слика 2 - PSNR предикција прве JND тачке на основу средње вредности амплитуде градијента

\section{JND prediction and image quality analysis}

The described model (Bondžulić et al, 2021) was used without any additional adjustments to determine the PSNR estimates of the first JND points of the reference images from the four datasets. For example, the adopted JND model is trained on high spatial resolution images (1280x1920 pixels), and will be tested on images that are of significantly lower resolution.

Figure 3 shows the scatter plots of subjective (mean opinion score MOS/difference MOS - DMOS) and objective (PSNR) quality scores. Each point on the scatter plots corresponds to one test image with JPEG compression. Scatter plots are shown for four image datasets, three of which are publicly available - LIVE (Sheikh et al, 2006) (with 29 original images), CSIQ (Larson \& Chandler, 2010) (with 30 original images) and VCL@FER (Zarić et al, 2012) (with 23 reference images). The fourth image dataset, marked with LWIR, will be publicly available soon, and can be obtained by sending an inquiry to the authors who created it (Merrouche et al, 2018). A subset of 100 images with JPEG compression was taken from the LWIR dataset containing images from the infrared part of the electromagnetic spectrum. The LWIR dataset test images were created from 20 original images, and their quality was reduced using five degradation levels (five quality factors). In subjective tests, the scores of 31 observers were collected. 
On the scatter plots, JPEG images are represented by two symbols, where the first symbol (o) corresponds to the images in which the PSNR of the test image is above the PSNR JND \#1 (this is the first class of images, which should consist of high quality images, and in which there is no loss of visual information). The second symbol $(\Delta)$ corresponds to the images for which the PSNR of the test image is below the PSNR JND \#1 (this is the second class of images that should consist of lower quality images). A similar idea of dividing images into two classes was used in (Ponomarenko et al, 2015).

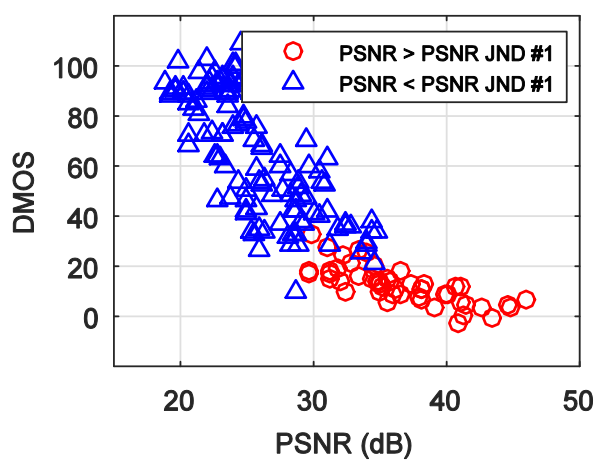

(a)

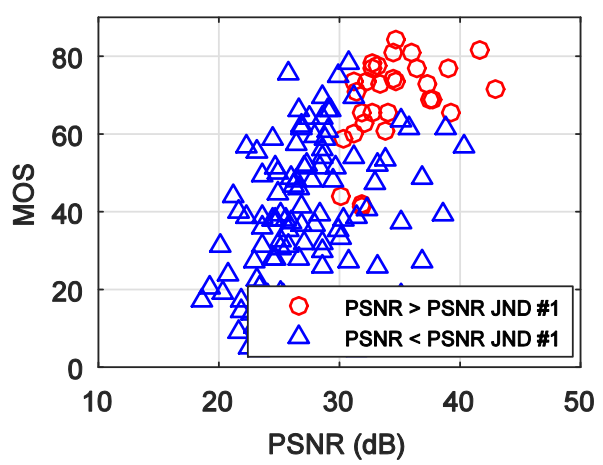

(c)

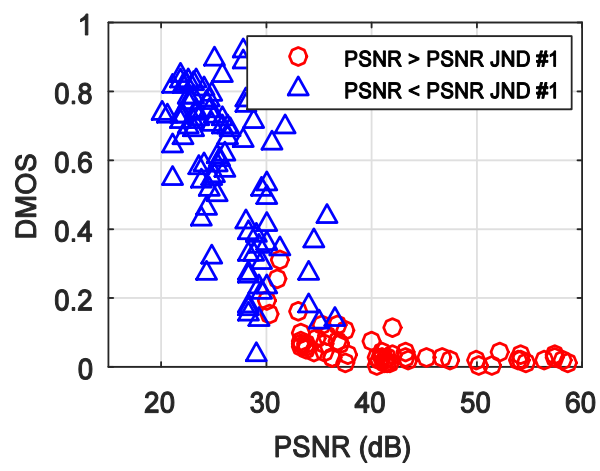

(b)

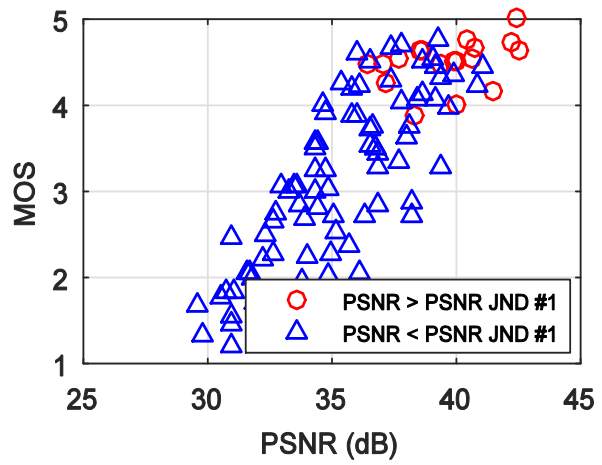

(d)

Figure 3 - Scatter plots of subjective and PSNR objective image quality scores for JPEG images from four datasets: (a) LIVE (175 images), (b) CSIQ (150 images), (c) VCL@FER (138 images) and (d) LWIR (100 images)

Puc. 3 - Диаграммы разброса субъективных оценок качества изображений и объективных оценок PSNR для изображений JPEG из четырех наборов данных:

(a) LIVE (175 изображений), (b) CSIQ (150 изображений), (c) VCL@FER (138 изображений) и (d) LWIR (100 изображений)

Слика 3 - Дијаграми расипања субјективних и PSNR објективних скорова квалитета JPEG слика из четири базе: (a) LIVE (175 слика), (b) CSIQ (150 слика), (c) VCL@FER (138 слика) и (d) LWIR (100 слика) 
Figure 3 shows that the proposed approach for the first JND point estimation proved to be excellent on the LIVE and CSIQ datasets. By applying the PSNR of the first JND point, images of excellent visual quality were detected - they correspond to lower values of subjective DMOS scores. Slightly worse results of the proposed first JND point estimation model can be seen for the images from the VCL@FER dataset.

The surprising result of the proposed approach can be seen on the LWIR image dataset. Although it is a dataset of images from the invisible (infrared) part of the electromagnetic spectrum, the proposed approach of the first JND point estimation has proven to be very successful in detecting JPEG compressed images with high quality - they correspond to higher values of subjective MOS scores. In this way, the validity of the proposed PSNR estimation of the first JND point was indirectly confirmed, using the results of subjective quality tests of available image datasets.

Figure 4 shows two source images from the LWIR dataset and their JPEG compressed versions for which the PSNR value is above the PSNR JND \#1. The test images are of excellent and good visual quality, i.e. there is no visual difference between the pair of images shown in Figures 4(a) and 4(b) $(\mathrm{MOS}=5)$, while the observers noticed slight differences between the pair shown in Figures 4(c) and 4(d) (MOS=4).

For the two selected examples, the degrees of image compression are approximately equal and are 21.7 (Figure 4a) and 23.3 (Figure 4b). 


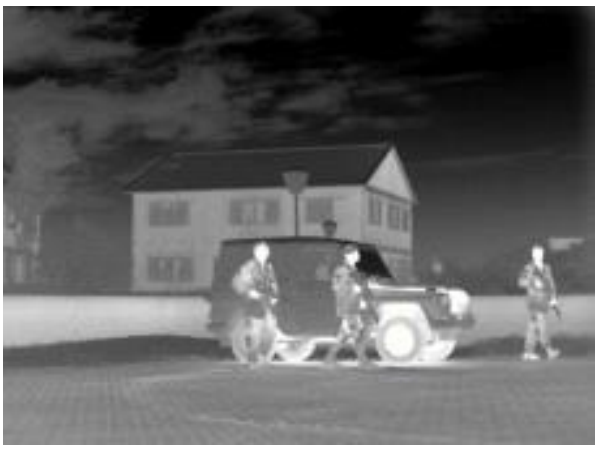

(a)

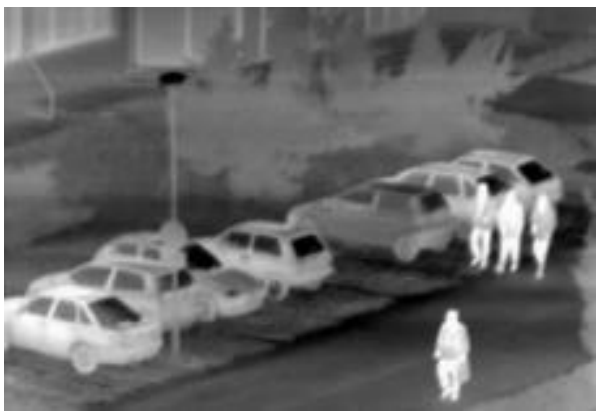

(c)

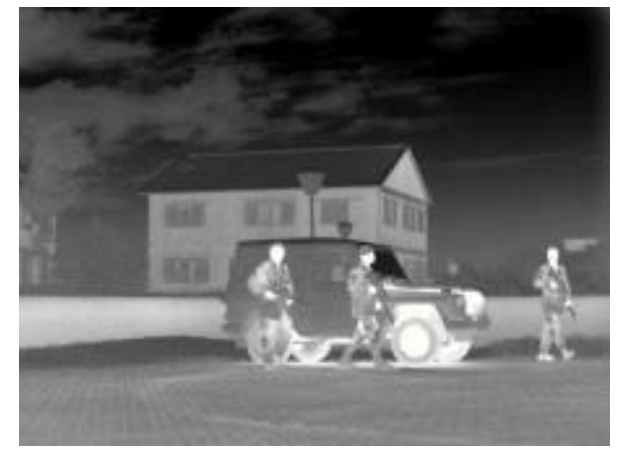

(b)

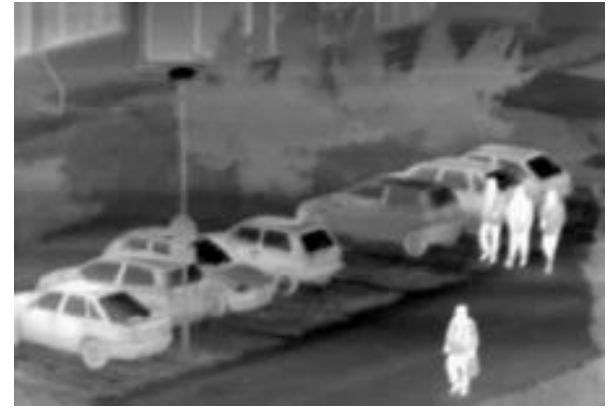

(d)

Figure $4-$ (a) original image (image size is $608 \mathrm{kB}$ ), (b) test image with JPEG compression ( $P S N R=42.47, P S N R$ JND \#1=39.92, MOS=5, image size is $28 \mathrm{kB}$ ), (c) original image (image size is $256 \mathrm{kB}$ ) and (d) test image with JPEG compression ( $P S N R=40.03, P S N R J N D \# 1=38.18, M O S=4$, image size is $11 \mathrm{kB}$ )

Puc. 4 - (a) исходное изображение (размер изображения 608 kB), (б) тестовое изображение со сжатием JPEG (PSNR=42.47, PSNR JND \#1=39.92,

$M O S=5$, размер изображения $28 \mathrm{kB}$ ), (в) исходное изображение (размер изображения $256 \mathrm{kB}$ ) и (d) тестовое изображение со сжатием JPEG (PSNR=40.03, $P S N R J N D \# 1=38.18, M O S=4$, размер изображения $11 \mathrm{kB})$

Слика 4 - (а) оригинална слика (величине 608 kB), (b) тест-слика са JPEG компресијом (PSNR=42,47, PSNR JND \#1=39,92, MOS=5, величина слике је 28 kB),

(c) ориаинална слика (величине 256 kB) и (d) тест-слика са JPEG компресијом (PSNR=40,03, PSNR JND \#1=38,18, MOS=4, величина слике је 11 kB)

\section{Impact of JND prediction on image quality assessment}

The described approach of the PSNR estimation of the first JND point is derived from the results of subjective tests of the MCL-JCI dataset (Jin et al, 2016) in which 50 original images are used. The degree of agreement between SQF subjective and objective quality scores on this JPEG image dataset is worse than the degree of agreement between subjective and objective quality scores on publicly 
available image datasets such as LIVE, CSIQ, VCL@FER and similar (Bondžulić et al, 2020). A very low degree of agreement between the SQF subjective and PSNR objective quality scores on this image dataset can be observed through the large spreading on the scatter plots shown in Figure 5. The scatter plots are shown for PSNR objective quality scores. The degraded images originating from the same original image are on the scatter plot in Figure 5(a) connected by lines of different colors. On the scatter plot in Figure 5(b), the images corresponding to the JND points derived from subjective tests are marked with different symbols (from JND \#1 to JND \#7).

Additionally, in Figure 5(a), it can be seen that the slope of the lines corresponding to the images originating from the same original image is approximately the same. The spreading in the space of subjective and objective quality scores is a consequence of the different content of the original images. Similar conclusions related to the PSNR performance in video quality assessment were reached by the authors in (Huynh-Thu \& Ghanbari, 2008), (Bondzulic et al, 2016). The goal of designing objective quality assessment measures is that the results of the assessment, among other things, do not depend on the content of the original images.

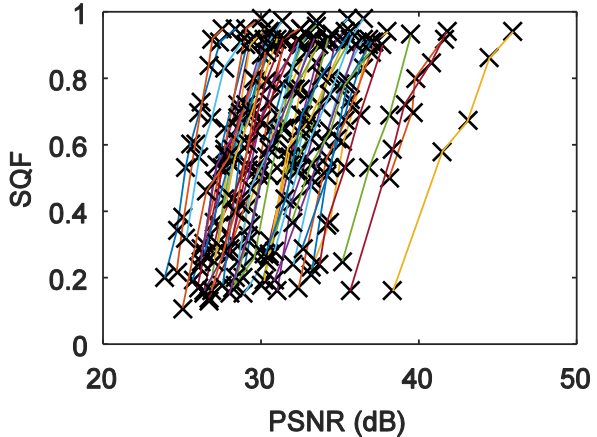

(a)

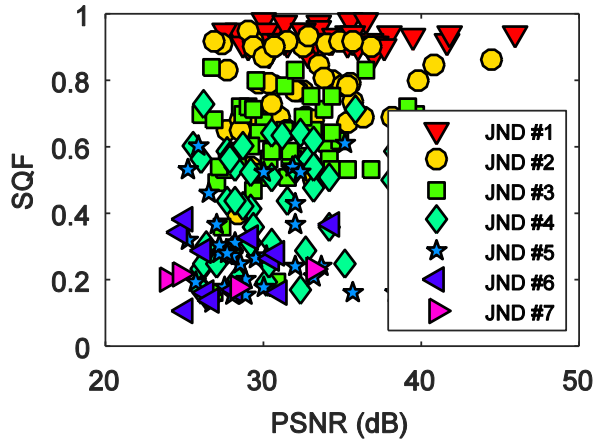

(b)

Figure 5-Scatter plots of subjective and PSNR objective quality scores of MCL-JCI JPEG compressed images: (a) the scatter plot is shown regarding the images originating from the same original image and (b) the scatter plot with marked JND points

Puc. 5- Диаграммы разброса субъективных оценок качества и объективных оценок PSNR сжатых изображений MCL-JCI JPEG: (a) график разброса показан в соответствии с изображениями, происходящими из одного и того же исходного изображения, $и(b)$ графрик разброса с отмеченными точками JND

Слика 5 - Дијаграми расипања субјективних и PSNR објективних скорова квалитета JPEG компримованих слика MCL-JCI базе: (a) дијаграм расипања је приказан према сликама које потичу од исте оригиналне слике и (b) дијаграм расипања са обележеним JND тачкама 
Figure 6(a) shows the curves of the JND points from the two source images, between which are the other JND points of the scatter plot between the SQF and PSNR scores on the MCL-JCI image dataset.

Figures 6(b) and 6(c) show the original images corresponding to the curves of Figure $6(\mathrm{a})$, i.e. the left and right boundaries on the scatter plot. It can be concluded that the points on the scatter plot are located between the JND points of the image with uniform regions and visible boundaries between them (right scatter border), and the image with a pronounced uniform region in the upper third of the image (with intensity saturation), and rich in details in the rest (left scatter border).

From Figure 5 it can be seen that the vertices of the curves start from the images corresponding to the first JND points. In order to make the result of the PSNR objective quality evaluation independent of the content of the original images, it is reasonable to define the differential PSNR as the difference between the PSNR and the estimation of the PSNR JND \#1:

$$
D P S N R=P S N R-P S N R J N D \# 1 .
$$

DPSNR values can be both positive and negative. Positive values correspond to good quality images (PSNR>PSNR JND \#1), while negative values correspond to lower quality images. Also, DPSNR is a picture-wise JND measure of objective image quality assessment. 


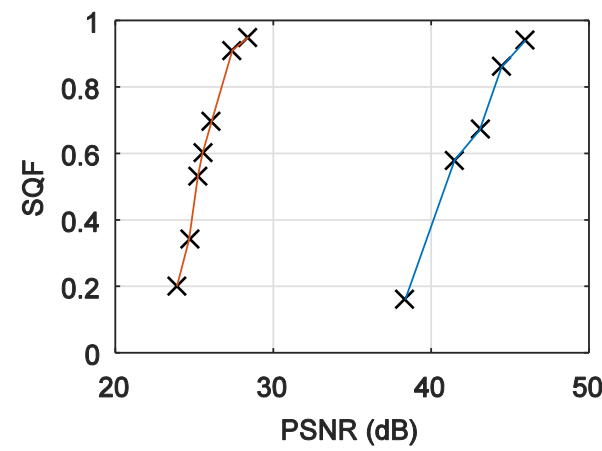

(a)

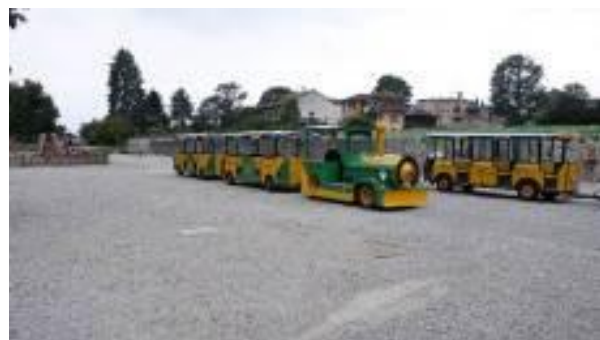

(b)

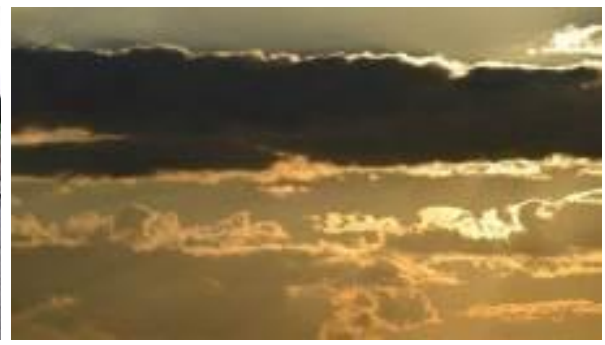

(c)

Figure 6- (a) the relationship between SQF and PSNR for the two source images of the $M C L-J C l$ dataset, (b) the original image corresponding to the left boundary of the JND points and (c) the original image corresponding to the right boundary of the JND points of the MCL-JCl image dataset

Puc. 6 - (a) взаимосвязь между SQF и PSNR для двух исходных изображений набора данных MCL-JCl, (b) исходное изображение, coответствующее левой границе точек JND, и (c) исходное изображение, соответствующее правой границе JND-точки набора данных изображения MCL-JCI

Слика 6 - (a) веза између SQF и PSNR за две изворне слике из MCL-JCI базе, (b) оригинална слика која одговара левој граници JND тачака и (c) оригинална слика која одговара десној граници JND тачака MCL-JCI базе слика

The scatter plots of subjective and DPSNR objective quality scores on the four analyzed image datasets are shown in Figure 7. Significantly less spreading of scores is observed in relation to the spreading of the scores of the PSNR objective measure (Figure 3). 


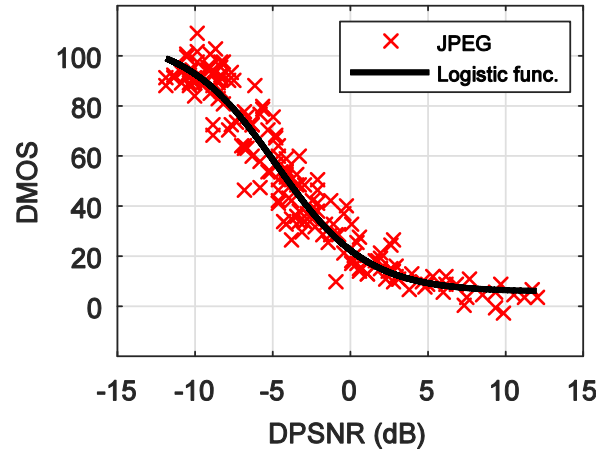

(a)

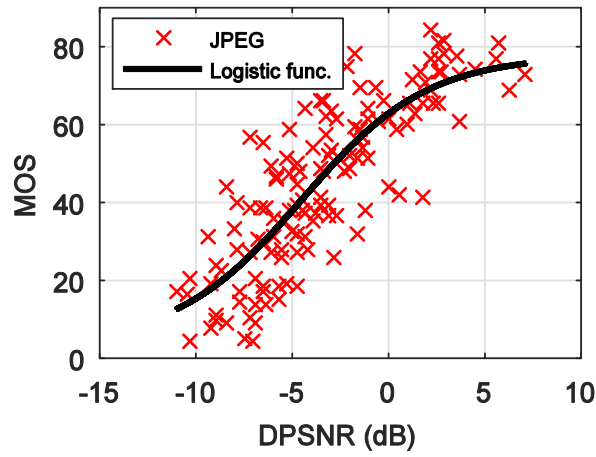

(c)

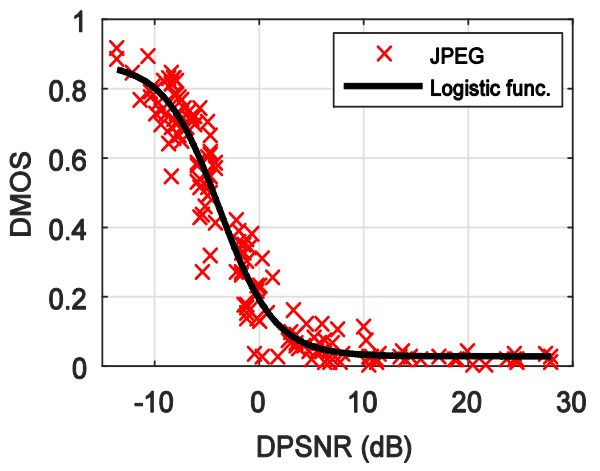

(b)

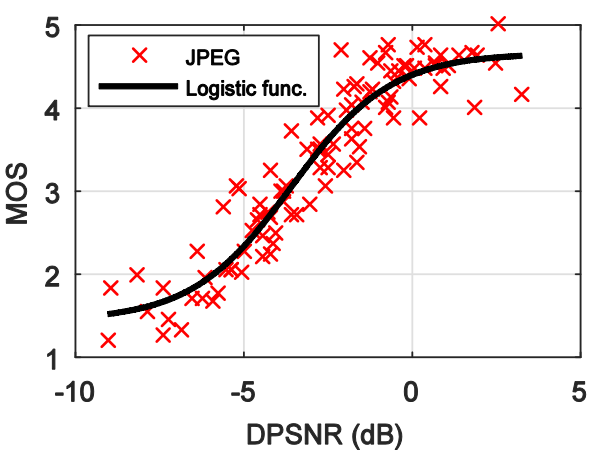

(d)

Figure 7-Scatter plots of subjective and DPSNR objective quality scores of images with JPEG compression on four datasets: (a) LIVE, (b) CSIQ, (c) VCL@FER and (d) LWIR

Puc. 7-Диаграммы разброса субъективных и объективных оценок качества DPSNR изображений со сжатием JPEG для четырех наборов данных: (a) LIVE, (b) CSIQ, (c) VCL@FER u (d) LWIR

Figure 7- Дијаграми расипања субјективних и DPSNR објективних скорова квалитета слика са JPEG компресијом за четири базе: (a) LIVE, (b) CSIQ, (c) VCL@FERu (d) LWIR

Table 1 provides the quantitative indicators of the degree of agreement between the subjective and PSNR/DPSNR objective quality scores for the four analyzed image datasets. The linear correlation coefficient (LCC), Spearman's rank-order correlation (SROCC), mean absolute error (MAE), root mean square error (RMSE) and outlier ratio (OR) between the subjective and objective quality scores after nonlinear regression using a logistic function with four parameters were used as quantitative indicators (ITU-T, 2004), (Bondžulić et al, 2018). In addition to the performance of these two objective measures, the performance of the HVS-based objective measures is given: PSNR-HVS (Egiazarian et al, 2006), PSNR-HVS-M (Ponomarenko et al, 2007) and WNMAE 


\begin{tabular}{|c|c|c|c|c|c|c|}
\hline \multicolumn{7}{|c|}{$\begin{array}{l}\text { (Huang et al, 2018). PSNR-HVS and PSNR-HVS-M measures are sub- } \\
\text { band models that take into account the contrast sensitivity function. } \\
\text { Additionally, PSNR-HVS-M takes into account the between-coefficient } \\
\text { contrast masking of the discrete cosine transform basis functions } \\
\text { (Ponomarenko et al, 2007). WNMAE is a traditional pixel-wise model } \\
\text { based on JND. Through this measure, HVS's physiological (color and } \\
\text { light sensitivity) and psycho-physiological (texture and edge sensitivity) } \\
\text { characteristics were implemented. The two best results for each dataset } \\
\text { and for each quantitative indicator are in Table } 1 \text { marked in bold. } \\
\text { Table 1- Performance comparison of objective measures on four datasets } \\
\text { Таблица 1- Сравнение эфрфективости объективных показателей по четырем } \\
\text { наборам данных } \\
\text { Табела 1- Поређење перформанси објективних мера на четири базе }\end{array}$} \\
\hline Dataset & Measure & LCC & SROCC & MAE & RMSE & OR [\%] \\
\hline \multirow{5}{*}{ LIVE } & PSNR & 0.8879 & 0.8809 & 11.3594 & 14.6532 & 12.5714 \\
\hline & DPSNR & 0.9649 & 0.9565 & 6.5225 & 8.3637 & 1.1429 \\
\hline & PSNR-HVS & 0.9585 & 0.9478 & 7.1802 & 9.0760 & 1.1429 \\
\hline & PSNR-HVS-M & 0.9752 & 0.9650 & 5.5549 & 7.0493 & 0.0000 \\
\hline & WNMAE & 0.9143 & 0.9113 & 9.9537 & 12.9013 & 5.7143 \\
\hline \multirow{5}{*}{ CSIQ } & PSNR & 0.8906 & 0.8879 & 0.0964 & 0.1391 & 31.3333 \\
\hline & DPSNR & 0.9707 & 0.9510 & 0.0547 & 0.0735 & 19.3333 \\
\hline & PSNR-HVS & 0.9577 & 0.9400 & 0.0603 & 0.0880 & 22.6667 \\
\hline & PSNR-HVS-M & 0.9733 & 0.9512 & 0.0501 & 0.0702 & 20.0000 \\
\hline & WNMAE & 0.8971 & 0.8962 & 0.0946 & 0.1352 & 34.0000 \\
\hline \multirow{5}{*}{ VCL@FER } & PSNR & 0.6041 & 0.6040 & 13.6027 & 16.7039 & 69.5652 \\
\hline & DPSNR & 0.8269 & 0.8262 & 9.2646 & 11.7856 & 52.1739 \\
\hline & PSNR-HVS & 0.8741 & 0.8775 & 7.8178 & 10.1823 & 48.5507 \\
\hline & PSNR-HVS-M & 0.9408 & 0.9388 & 5.5695 & 7.1051 & 33.3333 \\
\hline & WNMAE & 0.6252 & 0.6279 & 13.2803 & 16.3580 & 71.7391 \\
\hline \multirow{5}{*}{ LWIR } & PSNR & 0.8377 & 0.8146 & 0.4362 & 0.5650 & 59.0000 \\
\hline & DPSNR & 0.9481 & 0.9238 & 0.2596 & 0.3290 & 45.0000 \\
\hline & PSNR-HVS & 0.8238 & 0.8018 & 0.4573 & 0.5865 & 63.0000 \\
\hline & PSNR-HVS-M & 0.8389 & 0.8135 & 0.4492 & 0.5631 & 65.0000 \\
\hline & WNMAE & \multicolumn{5}{|c|}{ Not applicable } \\
\hline
\end{tabular}

The performance of the DPSNR objective measure is significantly better than the performance of the PSNR, for all five quantitative indicators and on four datasets. It can be noticed that the performance of the DPSNR is the worst on the VCL@FER image dataset, where the original PSNR has the worst results. 
The DPSNR performance is at the top on the LIVE and CSIQ datasets, along with the PSNR-HVS-M measure. Two sub-band models provide the best results on the VCL@FER image dataset, while the performance of the proposed DPSNR approach is best on the LWIR dataset of images from the infrared part of the electromagnetic spectrum. The performance of the WNMAE objective measure is slightly better than the performance of the worst ranked PSNR objective measure.

A careful reader may notice that in comparing the results of objective measures between different datasets (Table 1) one should be careful because different grading scales in subjective experiments have been used on different datasets (see Figures 3 and 5). The dynamic range of the grading scale affects the MAE and the RMSE. In this case, the LCC and SROCC values are relevant for comparing the results between the datasets.

The performance of objective measures was additionally analyzed on the MCL-JCl image dataset, which was used to train the estimation algorithms of the first JND point. Figure 8 shows the scatter plots of the SQF subjective and PSNR objective quality scores with image division into two classes, using PSNR JND \#1 values estimated using the approaches described in (Bondžulić et al, 2021) and (Lin et al, 2020).

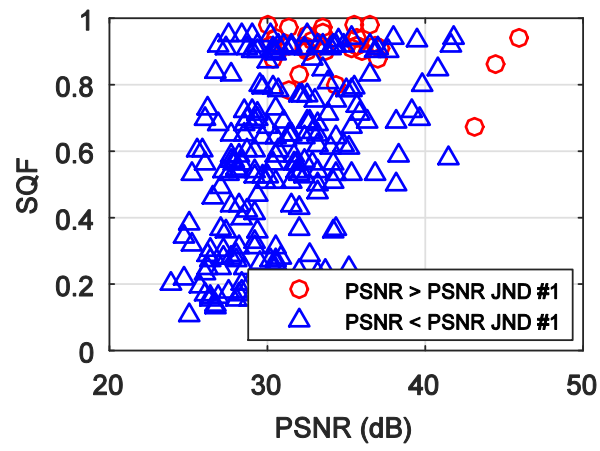

(a)

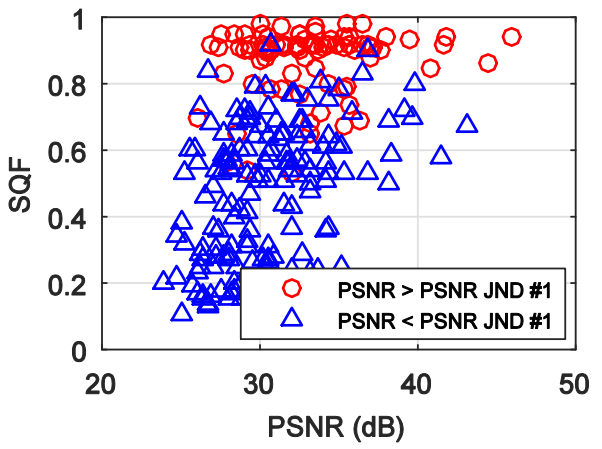

(b)

Figure 8 - Scatter plots of SQF subjective and PSNR objective scores on the MCL-JCI image dataset with division of images into two classes, where the estimates of PSNR JND \#1 were determined based on: (a) approach (Bondžulić et al, 2021) and (b) approach (Lin et al, 2020)

Puc. 8- Диаграммы разброса субъективных оценок SQF и объективных оценок PSNR в наборе данных изображений MCL-JCI с разделением изображений на два класса, где оценки PSNR JND \#1 были определены на основании: (a) подхода (Bondžulić et al, 2021) и (б) подхода (Lin et al, 2020)

Слика 8 - Дијаграми расипања SQF субјективних и PSNR објективних скорова на MCL-JCI бази са поделом на две класе слика, где се за одређивање PSNR JND \#1 користи: (a) приступ из (Bondžulić et al, 2021) и (b) приступ из (Lin et al, 2020) 
From Figure 8 it can be concluded that, by applying the approach (Lin et al, 2020), more JND \#1 points are detected than by applying the approach (Bondžulić et al, 2021) (additionally, see Figure 5(b)). It can also be observed that using this approach, several other (higher) JND points that are above the threshold of visible differences (PSNR JND \#1) were detected.

The values of the DPSNR objective measure were determined on the basis of two estimates of PSNR JND \#1 - the approaches described in (Bondžulić et al, 2021) and (Lin et al, 2020). The scatter plots of the SQF and DPSNR scores on the MCL-JCl dataset and the corresponding logistic functions are shown in Figure 9, while the quantitative indicators of the degree of their agreement are given in Table 2.

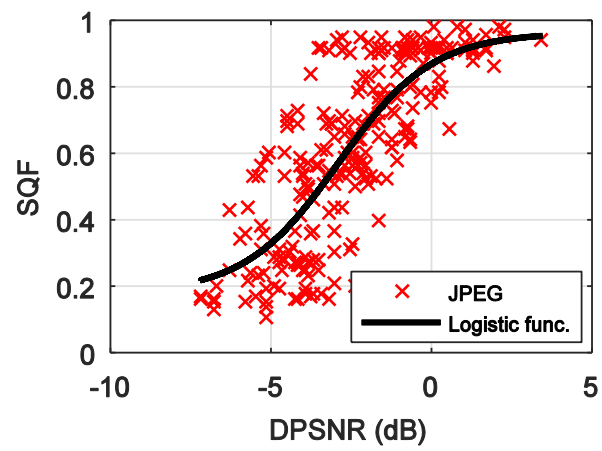

(a)

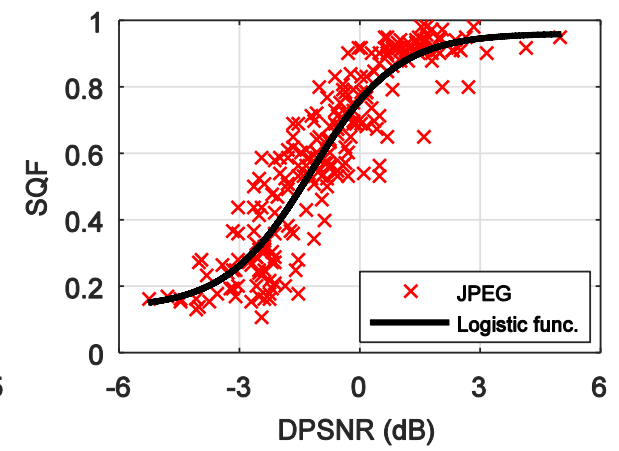

(b)

Figure 9 - Scatter plots of subjective and DPSNR objective scores on the MCL-JCl image dataset where the estimates of PSNR JND \#1 were determined based on: (a) approach (Bondžulić et al, 2021) and (b) approach (Lin et al, 2020)

Puc. 9- Диаграммы разброса субъективных оценок и объективных оценок DPSNR в наборе данных изображений MCL-JCl, где оценки PSNR JND \#1 были определены на основании: (a) подхода (Bondžulić et al, 2021) и (b) подхода (Lin et al, 2020)

Слика 9 - Дијаграми расипања субјективних и DPSNR објективних скорова MCLJCl базе слика, где се за одређивање PSNR JND \#1 користи: (а) приступ из (Bondžulić et al, 2021) и (b) приступ из (Lin et al, 2020)

From Figure 9 and from Table 2, it can be noticed that there is a significantly higher degree of agreement between the SQF and DPSNR objective quality scores determined using the PSNR JND \#1 estimates based on the approach from ( $\mathrm{Lin}$ et al, 2020). This result could be expected because this approach has a mean absolute PSNR JND \#1 estimation error of $0.58 \mathrm{~dB}$ on the MCL-JCl image dataset, while the approach described in (Bondžulić et al, 2021) has a higher estimation error $(1.21 \mathrm{~dB})$. In this case, although the poor performance of the 
baseline PSNR measure (LCC=0.4721), using PSNR JND \#1 the performance of DPSNR was significantly increased and exceeded the performance of other measures $(\mathrm{LCC}=0.9194)$.

Table 2 - Performance comparison of the objective measures on the MCL-JCI dataset

Таблица 2 - Сравнение производительности объективных показателей в наборе данных MCL-JCI

Табела 2 - Поређење перформанси објективних мера на MCL-JCI бази слика

\begin{tabular}{|c|c|c|c|c|c|}
\hline Dataset & Measure & LCC & SROCC & MAE & RMSE \\
\hline \multirow{4}{*}{ MCL-JCI } & PSNR & 0.4721 & 0.4486 & 0.1907 & 0.2288 \\
\cline { 2 - 6 } & DPSNR (Bondžulić et al, 2021) & 0.7973 & 0.7930 & 0.1222 & 0.1566 \\
\cline { 2 - 6 } & DPSNR (Lin et al, 2020) & $\mathbf{0 . 9 1 9 4}$ & $\mathbf{0 . 9 1 4 4}$ & $\mathbf{0 . 0 7 7 9}$ & $\mathbf{0 . 1 0 2 1}$ \\
\cline { 2 - 6 } & PSNR-HVS & 0.7679 & 0.7506 & 0.1328 & 0.1662 \\
\cline { 2 - 6 } & PSNR-HVS-M & $\mathbf{0 . 8 5 8 4}$ & $\mathbf{0 . 8 4 5 6}$ & $\mathbf{0 . 1 0 2 6}$ & $\mathbf{0 . 1 3 3 1}$ \\
\cline { 2 - 6 } & WNMAE & 0.4783 & 0.4665 & 0.1899 & 0.2279 \\
\hline
\end{tabular}

Although the introduction of the objective measure DPSNR has significantly improved the degree of agreement between subjective and PSNR objective quality scores, there is still room for improvement, and the degree of improvement will depend on the accuracy of PSNR JND \#1 estimation.

The position of the threshold of visible differences introduced in the quality assessment through PSNR JND \#1, in this paper improved the performance of PSNR on the class of images with JPEG compression. This is a consequence of reducing the dependence of objective estimates on the content of the source signal. We expect that with reliable estimation of the position of PSNR JND \#1 for other image classes (types of degradation), the performance of PSNR of individual classes will be improved, as well as the performance on a global level (reducing the dependence of estimates on the type of degradation).

\section{Conclusion}

The paper analyzes the reliability of one approach/model for the peak signal-to-noise ratio estimation of the visible differences (JND \#1 point) of images with JPEG compression. Reliability was confirmed in an indirect way by using the results of subjective tests of five available image datasets, i.e. it has been shown that by applying a peak signal-tonoise ratio of the first JND point, high quality images can be detected. As the proposed approach was derived on one of the analyzed image datasets, and the success was confirmed on the four remaining ones, it 
can be concluded that the findings derived from subjective tests on one dataset can be successfully used on other related datasets.

The paper additionally shows that the performance of the peak signal-to-noise ratio as a measure of objective quality assessment can be improved by taking into account the PSNR values of the first JND point. Improvement was achieved on image datasets with JPEG compression, through a significant increase in the degree of agreement between subjective and objective quality scores. Also, it has been shown that improving the accuracy of the estimation of the first JND point has a positive effect on the degree of agreement between subjective and objective assessments. Therefore, future work will be focused on improving the accuracy of the PSNR estimation of the threshold of visible differences, both for images with JPEG compression and for images with other types of degradation.

To the best of our knowledge, this is the first attempt to use JND information in quality assessment at the picture-wise level. Previous models have used pixel-based or sub-band JND visibility thresholds. The additional significance of the paper is reflected in the idea to indirectly analyze the success of the JND model through two-class image separation without conducting subjective tests, i.e. using already available subject-rated image datasets. Finally, the results are presented on JPEG compressed images originating from the visible and from the infrared part of the electromagnetic spectrum, which is of interest for remote sensing and surveillance applications.

\section{References}

Ahar, A., Mahmaoudpour, S., Van Wallendael, G., Paridaens, T., Lambert, P. \& Schelkens, P. 2018. A just noticeable difference subjective test for high dynamic range images. In: Proceedings of Tenth International Conference on Quality of Multimedia Experience (QoMEX), Cagliari, Italy, pp.1-6, May 29-June 1. Available at: https://doi.org/10.1109/QoMEX.2018.8463429.

Bondžulić, B.P., Pavlović, B.Z., Andrić, M.S. \& Petrović, V.S. 2017. Comments on objective quality assessment of JPEG images with visible differences. In: Proceedings of 13th International Conference on Advanced Technologies, Systems and Services in Telecommunications (TELSIKS), Niš, Serbia, pp.455-458, October 18-20. Available at: https://doi.org/10.1109/TELSKS.2017.8246323.

Bondžulić, B., Pavlović, B. \& Petrović, V. 2018. Performance analysis of full-reference objective image and video quality assessment metrics. Vojnotehnički glasnik/Military Technical Courier, 66(2), pp.322-350. Available at: https://doi.org/10.5937/vojtehg66-12708. 
Bondzulic, B., Pavlovic, B., Petrovic, V. \& Andric, M. 2016. Performance of peak signal-to-noise ratio quality assessment in video streaming with packet losses. Electronics Letters, 52(6), pp.454-456. Available at: https://doi.org/10.1049/el.2015.3784.

Bondžulić, B., Stojanović, N., Petrović, V. \& Zelmati, O. 2020. Using objective image quality assessment metrics in detection just noticeable differences of JPEG images. In: Proceedings of XXVI Conference and Exhibition YU INFO 2020, Kopaonik, Serbia, pp.203-208, March 8-11 [online]. Available at: http://www.yuinfo.org/ZBORNIK_YU_INFO_2020.pdf (in Serbian) [Accessed: 1 November 2021].

Bondžulić, B., Stojanović, N., Petrović, V., Pavlović, B. \& Miličević, Z. 2021. Efficient prediction of the first just noticeable difference point for JPEG compressed images. Acta Polytechnica Hungarica, 18(8), pp.201-220. Available at: https://doi.org/10.12700/APH.18.8.2021.8.11.

Egiazarian, K., Astola, J., Ponomarenko, N., Lukin, V., Battisti, F. \& Carli, M. 2006. Two new full-reference quality metrics based on HVS. In: Proceedings of 2nd International Workshop on Video Processing and Quality Metrics for Consumer Electronics - VPQM, Scottsdale, Arizona, USA, pp.1-4, January 2224.

Fan, C., Lin, H., Hosu, V., Zhang, Y., Jiang, Q., Hamzaoui, R. \& Saupe, D. 2019. SUR-Net: Predicting the satisfied user ratio curve for image compression with deep learning. In: Proceedings of 11th International Conference on Quality of Multimedia Experience, Berlin, Germany, pp.1-6, June 5-7. Available at: https://doi.org/10.1109/QoMEX.2019.8743204.

Gonzalez, R.C. \& Woods, R.E. 2018. Digital image processing, 4th Edition. London: Pearson Education, Inc. ISBN-13: 9780133356724.

Huang, J., Feng, H., Xu, Z., Li, Q. \& Chen, Y. 2018. A robust deblurring algorithm for noisy images with just noticeable blur. Optik - International Journal for Light and Electron Optics, 168, pp.577-589. Available at: https://doi.org/10.1016/j.ijleo.2018.04.052.

Hudson, G., Leger, A., Niss, B. \& Sebestyen, I. 2017. JPEG at 25: Still going strong. IEEE MultiMedia, 24(2), pp.96-103. Available at: https://doi.org/10.1109/MMUL.2017.38.

Hudson, G., Leger, A., Niss, B., Sebestyen, I. \& Vaaben, J. 2018. JPEG-1 standard 25 years: Past, present, and future reasons for a success. Journal of Electronic Imaging, 27(4), art.number:040901. Available at: https://doi.org/10.1117/1.JEl.27.4.040901.

Huynh-Thu, Q. \& Ghanbari, M. 2008. Scope of validity of PSNR in image/video quality assessment. Electronics Letters, 44(13), pp.800-801. Available at: https://doi.org/10.1049/el:20080522.

-ITU-T (Telecommunication Standardization Sector of ITU). 2004. Objective perceptual assessment of video quality: Full reference television. [online]. Available at: https://www.itu.int/ITUT/studygroups/com09/docs/tutorial_opavc.pdf [Accessed: 1 November 2021]. 
Jin, L., Lin, J.Y., Hu, S., Wang, H., Wang, P., Katsavounidis, I., Aaron, A. \& Kuo, C.-C. J. 2016. Statistical study on perceived JPEG image quality via MCL$\mathrm{JCl}$ dataset construction and analysis. In: Proceedings of IS\&T International Symposium on Electronic Imaging - Image Quality and System Performance XIII, San Francisco, CA, USA, art.number:IQSP-222, February 14-18. Available at: https://doi.org/10.2352/ISSN.2470-1173.2016.13.IQSP-222.

Larson, E.C. \& Chandler, D.M. 2010. Most apparent distortion: Fullreference image quality assessment and the role of strategy. Journal of Electronic Imaging, 19(1), art.number:011006. Available at: https://doi.org/10.1117/1.3267105.

Li, H., Jenadeleh, M., Chen, G., Reips, U-D., Hamzaoui, R. \& Saupe, D. 2020. Subjective assessment of global picture-wise just noticeable difference. In: Proceedings of IEEE International Conference on Multimedia \& Expo Workshops, London, UK, pp.1-6, July 6-10. Available at: https://doi.org/10.1109/ICMEW46912.2020.9106058.

Lin, H., Hosu, V., Fan, C., Zhang, Y., Mu, Y., Hamzaoui, R. \& Saupe, D. 2020. SUR-FeatNet: Predicting the satisfied user ratio curve for image compression with deep feature learning. Quality and User Experience, 5(5), pp.1-23. Available at: https://doi.org/10.1007/s41233-020-00034-1.

Liu, X., Chen, Z., Wang, X., Jiang, J. \& Kwong, S. 2018. JND-Pano: database for just noticeable difference of JPEG compressed panoramic images. In: Hong, R., Cheng, W.H., Yamasaki, T., Wang, M. \& Ngo, C.W. (Eds.) Advances in Multimedia Information Processing. PCM 2018. Lecture Notes in Computer Science, 11164, pp.458-468. Springer, Cham. Available at: https://doi.org/10.1007/978-3-030-00776-8_42.

Liu, H., Zhang, Y., Zhang, H., Fan, C., Kwong, S., Kuo, C-C.J. \& Fan, X. 2020. Deep learning based picture-wise just noticeable prediction model for image compression. IEEE Transactions on Image Processing, 29, pp.641-656. Available at: https://doi.org/10.1109/TIP.2019.2933743.

Lu, G., Zhang, X., Ouyang, W., Chen, L., Gao, Z. \& Xu, G. 2021. An endto-end learning framework for video compression. IEEE Transactions on Pattern Analysis and Machine Intelligence, 43(10), pp.3292-3308. Available at: https://doi.org/10.1109/TPAMI.2020.2988453.

Merrouche, S., Bondžulić, B., Andrić, M. \& Bujaković, D. 2018. Description and analysis of infrared image database - Subjective and objective image quality assessment. In: Proceedings of 8th International Scientific Conference on Defensive Technologies - OTEH, Belgrade, Serbia, pp.307-313, October 11-12 [online]. Available at: http://www.vti.mod.gov.rs/oteh18/elementi/rad/058.htm [Accessed: 1 November 2021].

Pennebaker, W.B. \& Mitchell, J.L. 1993. JPEG: Still image data compression standard. New York: Van Nostrand Reinhold Publishers. ISBN: 0442-01272-1. 
Ponomarenko, N., Lukin, V., Astola, J. \& Egiazarian, K. 2015. Analysis of HVS-metrics' properties using color image database TID2013. In: Battiato, S., Blanc-Talon, J., Gallo, G., Philips, W., Popescu, D. \& Scheunders, P. (Eds.) Advanced Concepts for Intelligent Vision Systems. ACIVS 2015. Lecture Notes in Computer Science, 9386, pp.613-624. Springer, Cham. Available at: https://doi.org/10.1007/978-3-319-25903-1_53.

Ponomarenko, N., Silvestri, F., Egiazarian, K., Carli, M., Astola, J. \& Lukin, V. 2007. On between-coefficient contrast masking of DCT basis functions. In: Proceedings of 3rd International Workshop on Video Processing and Quality Metrics for Consumer Electronics - VPQM, Scottsdale, Arizona, USA, pp.1-4, January 25-26 [online]. Available at: http://ponomarenko.info/vpqm07_p.pdf [Accessed: 1 November 2021].

Seo, S., Ki, S. \& Kim, M. 2021. A novel just-noticeable-difference-based saliency-channnel attention residual network for full-reference image quality predictions. IEEE Transactions on Circuits and Systems for Video Technology, 31(7), pp.2602-2616. Available at: https://doi.org/10.1109/TCSVT.2020.3030895.

Sheikh, H.R., Sabir M.F. \& Bovik, A.C. 2006. A statistical evaluation of recent full reference image quality assessment algorithms. IEEE Transactions on Image Processing, 15(11), pp.3440-3451. Available at: https://doi.org/10.1109/TIP.2006.881959.

Tian, T., Wang, H., Zuo, L., Kuo, C-C.J. \& Kwong, S. 2020. Just noticeable difference level prediction for perceptual image compression. IEEE Transactions on Broadcasting, 66(3), pp.690-700. Available at: https://doi.org/10.1109/TBC.2020.2977542.

Toprak, S. \& Yalman, Y. 2017. A new full-reference image quality metric based on just noticeable difference. Computer Standards \& Interfaces, 50, pp.18-25. Available at: https://doi.org/10.1016/j.csi.2016.08.003.

Wallace, G.K. 1992. The JPEG still picture compression standard. IEEE Transactions on Consumer Electronics, 38(1), pp.18-34. Available at: https://doi.org/10.1109/30.125072.

Wang, Z., Tran, T-H., Muthappa, P.K. \& Simon, S. 2019. A JND-based pixel-domain algorithm and hardware architecture for perceptual image coding. Journal of Imaging, 5(50), pp.1-29. Available at: https://doi.org/10.3390/jimaging5050050.

$\mathrm{Yu}, \mathrm{H}$. \& Winkler, S. 2013. Image complexity and spatial information. In: Proceedings of 5th International Workshop on Quality of Multimedia Experience - QoMEX, Klagenfurt am Worthersee, Austria, pp.12-17, July 3-5. Available at: https://doi.org/10.1109/QoMEX.2013.6603194.

Zarić, A., Tatalović, N., Brajković, N., Hlevnjak, H., Lončarić, M., Dumić, E. \& Grgić, S. 2012. VCL@FER image quality assessment database. Automatika, 53(4), pp.344-354. Available at: https://doi.org/10.7305/automatika.53-4.241. 


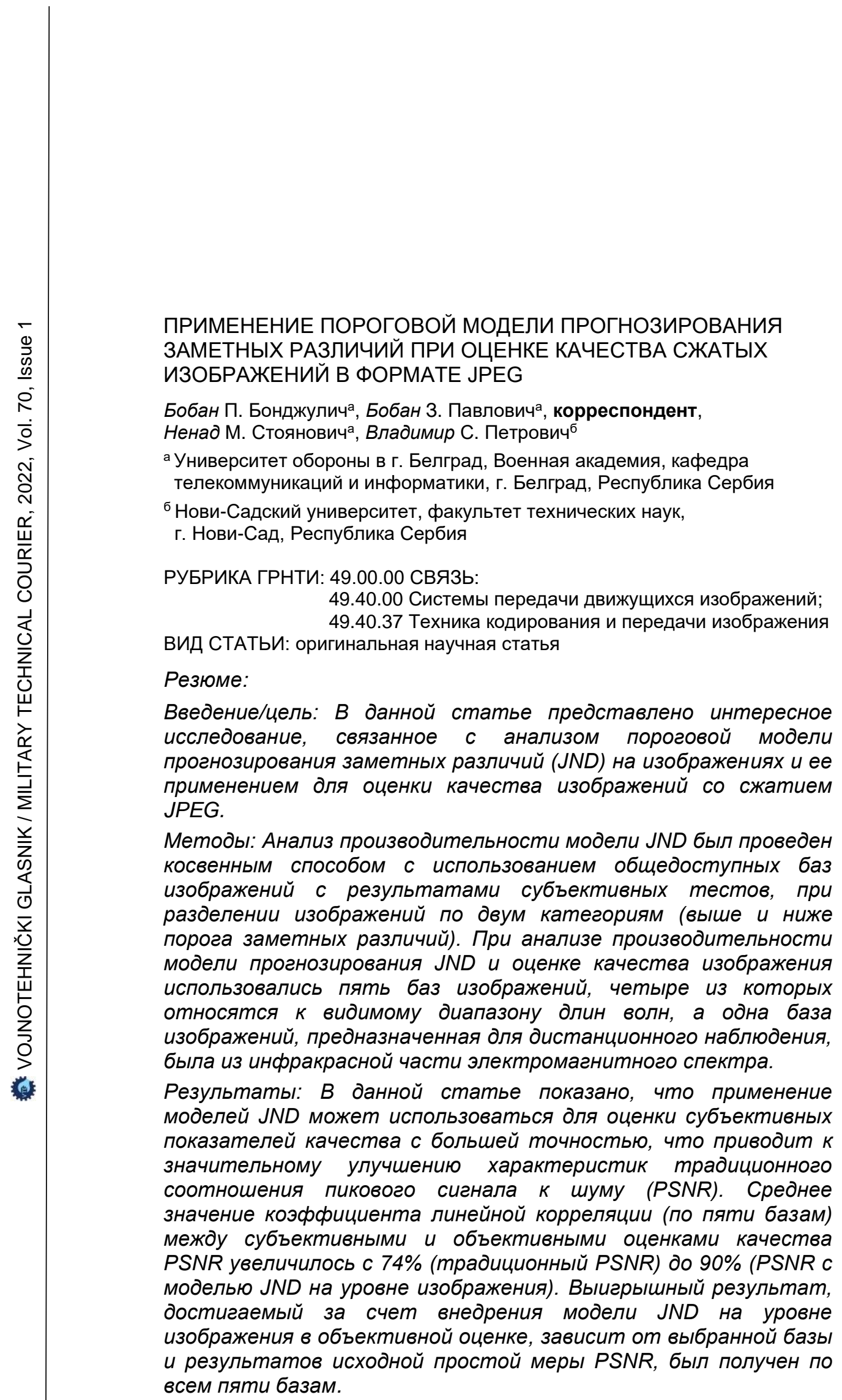


Выводы: Дополнительное улучшение объективной меры, основанной на JND, может быть достигнуто за счет улучшения наглядной модели прогнозирования JND.

Ключевые слова: порог заметных различий, сжатие JPEG, пиковое соотношение сигнал/шум, субъективная и объективная оценка качества изображения.

ПРИМЕНА МОДЕЛА ПРЕДИКЦИЈЕ ПРАГА УОЧЉИВИХ РАЗЛИКА У ПРОЦЕНИ КВАЛИТЕТА СЛИКА СА ЈРЕG КОМПРЕСИЈОМ

Бобан П. Бонџулића, Бобан 3. Павловића, аутор за преписку, Ненад М. Стојановић ${ }^{a}$, Владимир С. Петровић ${ }^{6}$

а Универзитет одбране у Београду, Војна академија, Катедра телекомуникација и информатике, Београд, Република Србија

б Универзитет у Новом Саду, Факултет техничких наука,

Нови Сад, Република Србија

ОБЛАСТ: телекомуникације

ВРСТА ЧЛАНКА: оригинални научни рад

\section{Сажетак:}

Увод/циљ: У раду су представљена интересантна истраживања која се односе на анализу перформанси модела предикције прага уочљивих разлика (JND) на нивоу слике и његову примену у процени квалитета слика са JPEG компресијом.

Meтоде: Анализа перформанси JND модела спроведена је на индиректан начин кроз занимљиву идеју да се користе јавно доступне базе слика са резултатима субјективних тестова, са поделом слика на две класе (изнад и испод прага уочљивих разлика). У анализи перформанси предикције JND модела и при процени квалитета коришћено је пет база слика, од којих четири потичу из видљивог опсега таласних дужина, док је једна база са сликама из инфррацрвеног дела електромагнетног спектра намењених даљинском осматрању и надзору.

Резултати: У раду је показано да се применом JND модела са већом прецизношћу могу естимирати субјективни скорови квалитета, што води значајном побољшању перформанси традиционалног вршног односа сигнал/шум (PSNR). Добитак остварен увођењем JND модела на нивоу слике у објективну процену зависи од изабране базе и резултата полазне једноставне PSNR мере, а остварен је на свих пет база. Средња вредност коефицијента линеарне корелације (за пет база) између субјективних и PSNR објективних естимација квалитета је са $74 \%$ 
(традиционални PSNR) порасла на 90\% (PSNR са JND моделом на нивоу слике).

Закључак: Додатно унапређење JND засноване објективне мере може се добити унапређењем модела предикције JND.

Кључне речи: праг уочљивих разлика, JPEG компресија, вршни однос сигнал/шум, субјективна и објективна процена квалитета слике.

Paper received on / Дата получения работы / Датум пријема чланка: 02.11.2021.

Manuscript corrections submitted on / Дата получения исправленной версии работы / Датум достављања исправки рукописа: 03.01.2022.

Paper accepted for publishing on / Дата окончательного согласования работы / Датум коначног прихватања чланка за објављивање: 04.01.2022.

(c) 2022 The Authors. Published by Vojnotehnički glasnik / Military Technical Courier (www.vtg.mod.gov.rs, втг.мо.упр.срб). This article is an open access article distributed under the terms and conditions of the Creative Commons Attribution license (http://creativecommons.org/licenses/by/3.0/rs/).

() 2022 Авторы. Опубликовано в «Военно-технический вестник / Vojnotehnički glasnik / Military Technical Courier» (www.vtg.mod.gov.rs, втг.мо.упр.срб). Данная статья в открытом доступе и распространяется в соответствии с лицензией «Creative Commons» (http://creativecommons.org/licenses/by/3.0/rs/).

() 2022 Аутори. Објавио Војнотехнички гласник / Vojnotehnički glasnik / Military Technical Courier (www.vtg.mod.gov.rs, втг.мо.упр.срб). Ово је чланак отвореног приступа и дистрибуира се у складу са Creative Commons licencom (http://creativecommons.org/licenses/by/3.0/rs/). 